\title{
Factors Contributing Ecological Footprint Awareness of Turkish Pre-Service Teachers
}

\author{
Şule Bayraktar ${ }^{1}$ \\ ${ }^{1}$ Faculty of Education, Giresun University, Giresun, Turkey \\ Correspondence: Şule Bayraktar, Faculty of Education, Giresun University, Giresun, Turkey.
}

Received: October 14, 2019

Accepted: November 20, 2019

Online Published: January 29, 2020

doi:10.5539/ies.v13n2p61

URL: https://doi.org/10.5539/ies.v13n2p61

\begin{abstract}
The purpose of this research is to determine ecological footprint awareness level of pre-service teachers who are majoring in three different programs of Teacher Education Department. The study also investigated whether there is a difference in ecological footprint awareness level based on gender, parents' education, program of study, and longest lived place of residence. "Ecological Footprint Awareness Scale" which was developed by Coşkun \& Sarıkaya (2014) was used as a data collection tool. The scale is a 5 point Likert type instrument which is composed of five dimensions related to food, shelter and mobility, water consumption, energy consumption, and waste management. One hundred and seventy pre-service teachers who are pursuing their third year in a College of Education of a medium size University located at northeast part of Turkey participated in the study. T-test and one-way analysis of variance (ANOVA) was used to analyze the data by utilizing SPSS statistical package. Results of the study revealed that the pre-service teachers' awareness on ecological footprint is at a medium level; highest levels of awareness found in energy $(X=4.15)$ and water consumption $(X=3.83)$ dimensions. Least level of awareness detected in food dimension $(X=3.04)$. Results of the study showed that pre-service teachers' awareness level differed based on gender in food dimension of the scale $(t=2.116, p<0.05)$ in favor of females. The results also showed that ecological awareness level of the pre-service teachers changed based on parents' education in water consumption and energy dimensions of the scale. Furthermore differences detected based on place of residence in favor of rural residents in energy and waste dimensions of the ecological footprint awareness. However, no significant difference was found based on the programs of pre-service teachers.
\end{abstract}

Keywords: ecological footprint awareness, pre-service teachers, gender, parental education

\section{Introduction}

Unconscious consumption of natural resources and irreversible damage caused by human activities to the nature dramatically influence the future of humanity. In many parts of the world, water and food shortages have begun, natural disasters such as floods and droughts have emerged at many points, and climate change and global warming have made it difficult to make the world a livable place. Consuming more than natural resources can compensate and emitting more carbon dioxide than trees can compensate bring more burden than the world can handle. Without a solution to these environmental problems, life in the world will not be possible after a certain period of time.

Environmental problems threatens not only those who created them but also the whole world. Therefore, all the countries of the world should be aware of the threat and the necessary precautions should be taken as a whole $(\mathrm{H}$. Baykal \& T. Baykal, 2008). For a sustainable life every individual and every society lives on the Earth should take responsibility and take necessary precautions by working cooperatively. In order for people to take part on this task they should be knowledgeable about which factors have direct or indirect impact on the sustainable life.

An important concept related to sustainable life is the ecological footprint which was introduced by Wackernagel and Rees (1998). Ecological footprint could be defined as the impact of human activities measured in terms of the area of biologically productive land and water required to produce the goods consumed and to assimilate the wastes generated (WWF). In other words, it is the amount of environment necessary to produce the goods and services necessary to support a particular lifestyle. Ecological footprint is calculated using the following formula:

$$
\text { Ecological footprint }=\text { Consumption } x \text { Necessary production area }
$$

The ecological footprint consists of six components: (1) Carbon: is the forest area that will be required to sequester 
carbon dioxide emissions from individuals' energy consumption (2) Cropland: means the land required to grow plants consumed by the individuals (3) Grazing Land: means the grazing area required to produce the necessary animal products; (4) Forests: area that will be required to produce wood and paper; (5) Fishing grounds: refers to freshwater and seas required to produce fish and seafood; (6) The Build up Land: refers to the area required for building residential areas and infrastructure. The ecological footprint consisting of these components could be calculated for individuals, institutions, cities, and countries. Individual footprint is related to personal use of the goods and services, such as food, energy and transportation; therefore strongly related with lifestyle and preferences of individuals. Understanding the relationship between people's lifestyles i.e. consumption habits with natural resources is crucial for raising awareness about the sustainable life (WWF, 2012).

Biocapacity of the Earth is another measure which is related to sustainable life. Biocapacity could be defined as Earth's ability to produce natural resources, provide land for humans to build on, and absorb waste such as carbon emissions. For a sustainable life ecological footprint should not exceed the Earth's biocapacity. According to Living Planet Report (WWF, 2018), through changes in technology and land management practices, biocapacity has increased about $27 \%$ in the past 50 years. However, it has not kept pace with human consumption: humanity's ecological footprint has increased about 190\% over the same time period. Therefore, it is now imperative to reduce the ecological footprint of the humanity in order to live a sustainable life.

Many studies have been carried out to determine ecological footprints of different groups or individuals in Turkey as well as many other countries. A study by Eren et al.(2017) with a sample of academicians working at a Faculty of Agriculture revealed that, the academicians' ecological footprint is smaller than national average, however greater the international average. They found difference based on gender and academic degree: females' footprints greater than males and the professors' footprints are smaller than the associate and assistant professors. However, these differences were not statistically significant. The researchers also detected differences department wise: the smallest footprint was held by the academicians in departments of Zootechnology and bio-system engineering.

Özbaş et al. (2019) determined that footprints of individuals have changed for different age groups. The researchers also investigated whether ecological footprints varied according to the education and income levels. They have concluded that for all the age ranges, ecological footprints of individuals with high economic income are higher than those with low economic income. Also, the ecological footprint of the males of the same income level is higher than the ecological footprints of the females.

A study conducted by Özgen and Demirci-Aksoy (2017), with a sample of 385 adults from different segments of the society in city of Ankara, showed that the individuals had a low level of ecological footprint awareness. In terms of different dimensions of the footprint awareness, the highest level of awareness was found in food and the lowest was in the energy dimension. It was also determined that there is a difference in favor of men in the dimensions of energy, waste and transport and housing. According to the results of the study, participants' level of education did not affect their ecological footprint awareness.

Ak1ll et al. (2008), with a sample comprising of university students and academic staff $(\mathrm{N}=241)$ found that the ecological footprint of the sample was greater than the national and international average. Although not statistically significant, males' footprints were larger than females. They also found that the ecological footprint was directly related to income.

Karatekin (2019) measured ecological citizenship levels of 219 in-service teachers from different branches. As a result of the study, it is seen that teachers are at the middle level in sustainable footprint dimension which is one of the 4 components of ecological citizenship. In this dimension of the ecological citizenship, teachers received the lowest score on organic food consumption. A study by Keleş et al. (2008) also revealed that food dimension made the greatest contribution to ecological footprint of pre-service teachers of different majors. They did not detect any differences in ecological footprint based on gender.

Several studies investigated the ecological footprint awareness level of teacher candidates. A study by Coşkun and Sarıkaya (2014) revealed that ecological footprint awareness of the pre-service primary teachers is higher in energy and water consumption dimensions and lowest in food dimension. Gender differences were detected in the dimensions of energy, waste management, and water consumption of the ecological footprint awareness in favor of females. They did not detect a difference with regard to parents' level of education.

In the study conducted by Yildiz (2014), it was found that science and technology teacher candidates had the largest footprint in the food dimension and the smallest footprint in the energy dimension. Ecological Footprint awareness levels of female teacher candidates were found to be significantly higher than male teachers.

Birand (2016) conducted a study to determine pre-school teacher candidates' ecological footprint awareness and 
environment-friendly behaviors. The results of this study revealed that the student teachers had highest ecological footprint awareness in energy dimension and the lowest awareness in water consumption dimension. On the other hand, the results revealed that, in terms of environment-friendly behaviors, pre-school teacher candidates' showed "economic behaviors" most frequently and recycling behaviors least. In addition, results showed that there is a high positive correlation between ecological footprint awareness and environment-friendly behaviors.

Results of a study by Günal, Yücel-Işıldar, and Atik (2018) revealed that the ecological footprint awareness of the students studying in biology department was more developed than engineering students. The study also determined that females' level of ecological footprint awareness is higher than males in food and waste management dimensions.

Knowledge, attitude, and awareness of individuals affect their actions. Individuals with higher level of ecological footprint awareness are assumed to have a behavior pattern showing a serious tendency to take responsibility for solving environmental problems. Teachers are highly influential on the development of environmental awareness, as well as, favorable environmental attitude and behavior in students. On the other hand, as individuals who will be playing an active role in creating such an attitude, teachers should hold a high level of awareness themselves. Therefore, identifying the ecological footprint awareness of pre-service teachers and planning necessary steps to promote this awareness is critical in creating environmentally-conscious future generations. Furthermore, information on the variables contributing footprint awareness would be beneficial on planning practices to increase awareness and promote a deeper understanding of environmental issues.

Many studies on the measurement of ecological footprint on the basis of individuals, products and services have been conducted so far. However, there are a limited number of studies conducted on ecological footprint awareness, and specifically focused on pre-service teachers. Furthermore, the existing studies produced conflicting results. This study by contributing the research on the subject might be helpful on reaching a more confident result.

In this study, it was aimed to determine the ecological footprint awareness of pre-service science, primary and pre-school teachers. In accordance with the purpose of the study, answers to the following questions were sought.

1) What are the participants' ecological footprint awareness level in food, transport and shelter, energy, waste, and water?

2) Are there significant differences in ecological footprints of pre-service teachers based on: gender, parents' level of education (i.e. highest level of schooling attained), longest lived place of residence, and program of study.

\section{Method}

\subsection{Participants}

A total of 170 pre-service teachers (135 females and 35 males) pursuing their third year in three different programs of Faculty of Education (Primary Education, Science Education, and Pre-school Education) participated in this study.

\subsection{Research Instrument}

"Ecological Footprint Awareness Scale" which was developed by Coşkun and Sarıkaya (2014) was employed to collect the data. The scale is a 5 point Likert type instrument which is composed of five dimensions with 40 items. In addition, there is the question of control that is not evaluated in the scale. The dimensions are related to food, shelter \& mobility, water consumption, energy consumption, and waste management. Cronbach alpha reliability coefficients for the dimensions of the Ecological Footprint Awareness Scale were found by Coşkun and Sarıkaya (2014) as follows: food: 0.70 , shelter \& mobility: 0.76, energy consumption:

0.86 , waste management: 0.81 and water consumption: 0.86 .

Sample scale items are presented below:

- I prefer plant based food instead of meat.

- I use energy saving bulbs at home, workplace or in office rather than classical incandescent lamps

- I collect domestic wastes such as cardboard, paper, metal, plastic etc. in different bags

- I travel to places in walking distance on foot or by bike.

- I don't run the washing machine or dishwasher if it is not completely full. 


\subsection{Data Collection}

"Ecological Footprint Awareness Scale" was administered to pre-service teachers $(N=170)$ pursuing their third year in the Faculty of Education of a state university in Northeastern part of Turkey at the beginning of fall semester of the 2018-2019 school year. Student teachers were given as much time as they desired to complete the scales.

\subsection{Data Analyses}

In analyzing the data, the normality test was performed. After establishing the normality condition, statistical techniques of means, $t$-test, and Analysis of Variance (ANOVA) were used to analyze the data. In order to investigate whether there is a gender difference in ecological footprint awareness of pre-service teachers, scores on the scale were compared for male and female students by utilizing the $t$-test. ANOVA was performed to investigate whether there are differences in ecological footprint awareness regarding parents' educational level, longest lived place of residence, and program of study. Alpha was set at .05 level of significance for all tests.

\section{Results}

Pre-service teachers' scores for different dimensions of Ecological Footprint Awareness Scale were presented on Table 1.

Table 1. Descriptive statistics for ecological footprint awareness scores of the pre-service teachers

\begin{tabular}{lccccc}
\hline Dimensions & $\mathrm{N}$ & Min & Max & Mean & SD \\
\hline Food & & 1.62 & 4.25 & 3.04 & 0.53 \\
Shelter \& Mobility & & 1.22 & 4.89 & 3.30 & 0.67 \\
Energy & 170 & 2.53 & 5.00 & 4.15 & 0.53 \\
Waste & & 2.56 & 5.00 & 3.75 & 0.58 \\
Water & & 1.60 & 5.00 & 3.83 & 0.69 \\
\hline
\end{tabular}

Mean scores for the dimensions of the scale change between 3.04 and 4.15. The highest score was found for Energy dimension (4.15) and the lowest score was found for Food dimension (3.04). The scores for shelter \& mobility, waste management, and water consumption dimensions are 3.30, 3.75, and 3.83 respectively.

Table 2. Ecological footprint awareness scores of the respondents by gender

\begin{tabular}{lcccccc}
\hline Dimension & Gender & $\mathrm{N}$ & $\mathrm{M}$ & $\mathrm{SD}$ & $\mathrm{t}$ & $\mathrm{p}$ \\
\hline \multirow{2}{*}{ Food } & $\mathrm{F}$ & 135 & 3.08 & 0.51 & 2.116 & $0.036^{*}$ \\
& $\mathrm{M}$ & 35 & 2.87 & 0.57 & & \\
\multirow{2}{*}{ Shelter \& Mobility } & $\mathrm{F}$ & 135 & 3.34 & 0.67 & 1.394 & 0.165 \\
& $\mathrm{M}$ & 35 & 3.16 & 0.66 & & \\
\multirow{2}{*}{ Energy } & $\mathrm{F}$ & 135 & 4.18 & 0.53 & 1.888 & 0.061 \\
& $\mathrm{M}$ & 35 & 3.99 & 0.53 & & \\
\multirow{2}{*}{ Waste } & $\mathrm{F}$ & 135 & 3.78 & 0.59 & 1.702 & 0.091 \\
\multirow{2}{*}{ Water } & $\mathrm{M}$ & 35 & 3.60 & 0.54 & & \\
& $\mathrm{~F}$ & 135 & 3.87 & 0.70 & 1.595 & 0.113 \\
\hline
\end{tabular}

Current study showed a statistically significant difference based on gender in food dimension of the ecological footprints: females holding higher level of awareness $(X=3.08)$ compare to males (2.87). Females' level of awareness in other dimensions, although not statistically significant, is also found higher than males. 
Table 3. Ecological footprint awareness scores of the respondents by mother's educational level

\begin{tabular}{ccccccc}
\hline Dimension & Education & $\mathrm{N}$ & $\mathrm{M}$ & $\mathrm{SD}$ & $\mathrm{F}$ & $\mathrm{p}$ \\
\hline \multirow{5}{*}{ Food } & Primary & 105 & 3.05 & 0.56 & & \\
& Middle & 26 & 3.02 & 0.45 & 1.22 & 0.30 \\
& High & 24 & 3.17 & 0.45 & & \\
& University & 15 & 2.84 & 0.54 & & \\
\hline \multirow{2}{*}{ Shelter } & Primary & 105 & 3.27 & 0.66 & & \\
$\&$ & Middle & 26 & 3.42 & 0.65 & & \\
Mobility & High & 24 & 3.49 & 0.59 & 1.80 & 0.15 \\
& University & 15 & 3.03 & 0.79 & & \\
\hline \multirow{5}{*}{ Energy } & Primary & 105 & 4.18 & 0.52 & & \\
& Middle & 26 & 4.10 & 0.63 & & \\
& High & 24 & 4.18 & 0.38 & & 0.28 \\
& University & 15 & 3.91 & 0.59 & & \\
\hline \multirow{5}{*}{ Waste } & Primary & 105 & 3.79 & 0.59 & & \\
& Middle & 26 & 3.69 & 0.66 & & \\
& High & 24 & 3.71 & 0.47 & & 0.74 \\
& University & 15 & 3.65 & 0.59 & & \\
\hline \multirow{5}{*}{ Water } & Primary & 105 & 3.93 & 0.66 & & \\
& Middle & 26 & 3.82 & 0.76 & \multirow{2}{*}{2.8} & $0.038^{*}$ \\
& High & 24 & 3.63 & 0.62 & & \\
& University & 15 & 3.46 & 0.74 & & \\
\hline \multirow{5}{*}{ \& } & & & & & &
\end{tabular}

Table 3 shows that awareness scores of PST's whose mothers' holding primary, middle, or high school degree are close to each other. However, scores of PST's whose mothers holding higher education degree are found lower than the other groups. The difference, on the other hand, found to be statistically significant in only water dimension $(\mathrm{F}=2.874, \mathrm{p}<0.05)$.

Table 4. Ecological footprint awareness scores of the respondents by father's educational level

\begin{tabular}{|c|c|c|c|c|c|c|}
\hline Dimension & Education & $\mathrm{N}$ & $\mathrm{M}$ & $\mathrm{SD}$ & $\mathrm{F}$ & $\mathrm{p}$ \\
\hline \multirow{4}{*}{ Food } & Primary & 63 & 3.113 & .609 & \multirow{4}{*}{0.700} & \multirow{4}{*}{.554} \\
\hline & Middle & 39 & 3.003 & .491 & & \\
\hline & High & 31 & 3.036 & .469 & & \\
\hline & University & 37 & 2.966 & .469 & & \\
\hline \multirow{4}{*}{ Shelter } & Primary & 63 & 3.345 & .734 & \multirow{4}{*}{0.525} & \multirow{4}{*}{.666} \\
\hline & Middle & 39 & 3.367 & .623 & & \\
\hline & High & 31 & 3.272 & .603 & & \\
\hline & University & 37 & 3.198 & .664 & & \\
\hline \multirow{4}{*}{ Energy } & Primary & 63 & 4.275 & .522 & \multirow{4}{*}{2.699} & \multirow{4}{*}{$.047 *$} \\
\hline & Middle & 39 & 4.073 & .541 & & \\
\hline & High & 31 & 4.167 & .549 & & \\
\hline & University & 37 & 3.985 & .482 & & \\
\hline \multirow{4}{*}{ Waste } & Primary & 63 & 3.848 & .628 & \multirow{4}{*}{1.326} & \multirow{4}{*}{.268} \\
\hline & Middle & 39 & 3.661 & .561 & & \\
\hline & High & 31 & 3.781 & .562 & & \\
\hline & University & 37 & 3.645 & .537 & & \\
\hline \multirow{4}{*}{ Water } & Primary & 63 & 3.987 & .669 & \multirow{4}{*}{2.096} & \multirow{4}{*}{.103} \\
\hline & Middle & 39 & 3.697 & .664 & & \\
\hline & High & 31 & 3.832 & .779 & & \\
\hline & University & 37 & 3.691 & .647 & & \\
\hline
\end{tabular}

Table 4 shows that, in all dimensions of the ecological footprint awareness scale, scores are closer for PST's whose fathers are primary, middle or high school graduate, while the scores for the PST's whose fathers holding college degree are considerably lower than the others. However, the difference was found statistically significant only for 
energy dimension.

Table 5. Ecological footprint awareness scores of the respondents by father's educational level

\begin{tabular}{ccccccc}
\hline Dimension & Residential Place & $\mathrm{N}$ & $\mathrm{M}$ & $\mathrm{SD}$ & $\mathrm{F}$ & $\mathrm{p}$ \\
\hline \multirow{3}{*}{ Food } & Village & 24 & 3.11 & 0.65 & 0.234 & 0.791 \\
& Town & 67 & 3.04 & 0.52 & & \\
& City & 79 & 3.03 & 0.50 & & \\
\multirow{3}{*}{ Shelter\& Mobility } & Village & 24 & 3.59 & 0.62 & 2.543 & 0.082 \\
& Town & 67 & 3.27 & 0.56 & & \\
& City & 79 & 3.25 & 0.75 & & \\
Energy & Village & 24 & 3.59 & 0.43 & 3.358 & $0.037^{*}$ \\
& Town & 67 & 3.27 & 0.47 & & \\
& City & 79 & 3.25 & 0.59 & & \\
Waste & Village & 24 & 4.40 & 0.51 & 4.594 & $0.011^{*}$ \\
& Town & 67 & 4.11 & 0.48 & & \\
& City & 79 & 4.10 & 0.66 & & \\
& Village & 24 & 4.08 & 0.62 & 1.870 & 0.157 \\
& Town & 67 & 3.76 & 0.69 & & \\
& City & 79 & 3.81 & 0.71 & & \\
\hline
\end{tabular}

Table shows that in all dimensions of the footprint awareness the PST's who lived in a village are highest and the scores of PST's who lived in towns or cities are close to each other. However, difference in scores was significant in only waste $(\mathrm{F}=4.594, \mathrm{p}<0.05)$ and energy dimension $(\mathrm{F}=3.358, \mathrm{P}<0.05)$.

Table 6. Ecological footprint awareness scores of the respondents by program of study

\begin{tabular}{ccccccc}
\hline \multirow{2}{*}{ Dimension } & $\begin{array}{c}\text { Program } \\
\text { (Teacher Ed.) }\end{array}$ & $\mathrm{N}$ & $\mathrm{M}$ & $\mathrm{SD}$ & $\mathrm{F}$ & $\mathrm{p}$ \\
\hline \multirow{3}{*}{ Food } & Primary & 74 & 3.03 & 0.53 & 0.083 & 0.920 \\
& Science & 62 & 3.04 & 0.56 & & \\
& Pre-school & 34 & 3.07 & 0.48 & & \\
Shelter\& Mobility & Primary & 74 & 3.23 & 0.61 & 1.103 & 0.334 \\
& Science & 62 & 3.40 & 0.66 & & \\
& Pre-school & 34 & 3.31 & 0.80 & & \\
Energy & Primary & 74 & 4.15 & 0.47 & 0.517 & 0.597 \\
& Science & 62 & 4.18 & 0.56 & & \\
& Pre-school & 34 & 4.07 & 0.60 & & \\
Waste & Primary & 74 & 3.65 & 0.54 & 2.227 & 0.111 \\
& Science & 62 & 3.86 & 0.60 & & \\
& Pre-school & 34 & 3.78 & 0.62 & & \\
& Primary & 74 & 3.75 & 0.68 & 0.935 & 0.395 \\
& Science & 62 & 3.86 & 0.74 & & \\
& Pre-school & 34 & 3.94 & 0.63 & & \\
\hline
\end{tabular}

As seen on Table 6, the scores of PST' $s$ who study at different teacher education programs were found to be very close to each other with pre-service science teachers' slightly higher than the others. There were no significant differences according to program of study in PST's ecological footprint awareness.

\section{Discussion}

Results of the current study showed that pre-service primary teachers have relatively high level of awareness on the ecological footprint. Their awareness level on the energy and water consumption dimensions found to be higher than the other dimensions. This result consisted with previous research reporting that the highest level of the awareness found on the dimensions of energy and water consumption and lowest level of the awareness found in food dimension of the ecological footprint (Coşkun, 2013; Keleş, 2007; Keleş et al., 2008; Şahin, Erkal, \& Ateşoğlu, 2018; Günal et al., 2018). 
Use of renewable energy sources and conscious consumption of energy are now on the agenda because of increasing energy demand in all over the world. Topic of efficient use of energy takes place in the curricula of certain courses at all level of educational institutions as well as is discussed in media. This might be major reason for higher level of awareness in this dimension. Another dimension with the highest ecological footprint is the "water consumption" dimension. This result is expected because water consumption like energy consumption is regarded as an important issue for saving the nature hence efficient use of water was emphasized by educational institutions and mass media. However, in addition to the tendency towards the conservation of natural resources, people might be showing this behavior due to economical reasons. Indeed, a study by Özbaş et al. (2019) revealed that the ecological footprints of individuals with high income level are greater than individuals with low income level.

Pre-service teachers' level of footprint awareness found lowest in food dimension. Organic foods and food safety are relatively new concepts for most part of the society in Turkey. Although the curricula in schools contains chapters related to conscious use of energy and water for a long time, issues such as environmentally conscious food consumption are not included in the curricula. Besides education, difficulty of reaching out organic food and the high cost of it might be a reason for it not to be preferred. In fact, this is a problem of organic farming in Turkey. Although Turkey have a strong background in agriculture, organic farming newly started to develop, the cost of organic products are very high and exceeds purchasing power of most people.

The items of the scale in this dimension were not only about the organic food; there were other items related to issues such as fast food consumption and consumption of vegetables in the right season. Pre-service teachers participated in this research as well as in other research did not show a desired level of awareness on these issues. The pre-service teachers' limitations such as not having enough time, skills, and medium to reach out and/or prepare healthy food might be a reason for preferring fast food. On the other hand, they might not have developed healthy eating habits since their parents were also not conscious about the issue.

Pre-service teachers' level of awareness on the shelter \& mobility is also relatively low for this particular sample. The participants of this research generally do not have much choice for the transportation in the region where the college situated, and the houses or dormitories they live are not suitable to make necessary changes to reduce the ecological footprints. These conditions might have a considerable effect on this particular finding.

Females found to be more aware of ecological footprint than males in the present study, however the result is statistically significant only in food dimension, there are other studies reporting similar results. For example, Coşkun and Sarıkaya (2014) with a sample of 376 pre-service primary teachers found that there are gender differences in the dimensions of energy, waste management, and water consumption in favor of females. Another research by Şahin, Erkal, and Ateşoğlu (2018) with a sample of pre-school pre-service teachers reported gender differences in ecological footprint awareness. Similar results were reported by other studies with different sample types (Akıllı et al., 2008; Günal et al., 2018; Özbaş et al., 2019; Yıldız, 2014). This result is also consistent with studies conducted in different countries revealing that men consume more energy than women (Medina \& Toledo-Bruno, 2016; Räty \& Carlsson-Kanyama, 2009).

This finding might be related to females' taking care of household chores more than men and caring more about the nature. Activities related to food and waste is generally considered as tasks for women rather than men in a traditional family structure. Indeed, a study by Sadık and Çakan (2010) revealed that female students have more favorable attitudes and behavior towards environment. Researchers suggested that the roles that society attributes to women might have supported the development of positive attitudes and behaviors. Similarly, a study by Tayci and Uysal (2012), with primary and secondary school students revealed that girls are more environmentalist, they tend to be more interested and sensitive towards the environment than boys.

Although most studies reported females' higher level of environmental awareness, there are other studies which did not detect any differences based on gender on ecological footprints awareness (Ağaç \& Yalçın, 2017; Keleş et al., 2008; Keleş, 2011). Furthermore, studies by Özgen and Demirci-Aksoy (2017) and Eren et al. (2017) found differences in favor of males. Different results obtained from the studies on the subject could be related to the characteristics of the samples such as major in college and socio-economical status.

This study revealed significant differences in ecological footprints based on parents' educational level on the water consumption dimension with mother's educational level and on the energy dimension with father's educational level. The awareness level of the pre-service teachers with high-educated parents found to be lowest for the present study. In fact, highly educated individuals are expected to be more sensitive about the environment and have educated their children in this direction. Some research findings support this idea. Şahin, Erka, and Ateşoğlu (2018) for example, with a sample of pre-service pre-school teachers found that participants whose parents had a 
university degree have the highest ecological footprint awareness. On the other hand, Coşkun and Sarıkaya (2014) with primary school teacher candidates did not detect any differences based on parents' education. Similarly Petrovic et al. (20012) reported no significant differences among students with different parental educational level.

Income level of these particular participants might have an impact on this conflicting result. Since educational level has a considerable effect on income level, reason for differences might be related to income level rather than parents' educational level. That is, parents with university degrees might have greater income level comparing with the less educated parents. Their footprint awareness might be lower because of the difference in income level rather than the educational level. As mentioned earlier, income has a negative influence on ecological footprint awareness; since when income increases consumption of people increase accordingly (Özbaş et al., 2019). On the other hand, the number of parents holding higher education degree in this particular sample is considerably low. Therefore, it might not be appropriate to draw such a conclusion. Furthermore, the higher level of education does not qualify parents to be environmentally conscious individuals. They might not have sufficient knowledge related to ecology. Furthermore, their attitudes and habits might not be environment friendly. Therefore, despite the higher level of education, their awareness on ecological footprint might not have developed accordingly.

The present study detected differences based on type of residential area in favor of pre-service teachers who lived in rural areas, however this result was found to be statistically significant in only energy and waste dimension. This finding is consistent with the study conducted by Coşkun and Sarıkaya (2014) reporting significant differences based on place of residence on food, shelter \& mobility, and energy dimensions of the ecological footprint awareness. Although most studies (Berenguer et al., 2005; Hinds \& Sparks, 2008, Kahyaoğlu \& Özgen, 2012; Zengin \& Kunt; 2013) suggested that people who live in rural areas are more environmentally conscious, there are other studies reporting that type of residential area whether it was rural or urban, was not a significant factor in ecological footprint awareness (Birand, 2016; Günal et al., 2018; Yürüdür et al., 2017).

People who live in rural areas consume less energy and they have more practical and environment-friendly solutions for the waste management. For example they can feed their animals with the waste food and they produce less waste than the city people because they don't consume package food as much as them. On the other hand, living in an environment very close to the nature might have an impact on developing high level of environmental consciousness in participants. In fact, Huddart-Kennedy et al. (2009) found that rural residents, scored higher on altruistic values, placed a higher priority on the environment, and reported higher participation in recycling and stewardship behaviors compare to urban residents. Therefore it is reasonable for them to have a higher level of footprint awareness.

Considering that the people living in rural areas have a certain income level, it can be said that higher level of awareness on energy and waste dimension might have been related to the income level as well. To understand whether the difference comes from parents' educational level or income level, income level can be considered as a sub-category and its relation with the ecological footprint awareness of rural and urban residents could be examined. In fact, a study investigating ecological footprints of individuals in different age groups revealed that the ecological footprints of those with better economic status were greater in each age group (Özbaş et al., 2019).

Ecological footprint awareness of PST s did not change based on pre-service teachers' program of study in this research. This result is inconsistent with other research on the subject. For example, Ünal (2019) compared ecological citizenship levels of pre-service teachers studying in different programs. He found that ecological citizenship level of pre-service social studies teachers significantly higher than the pre-service primary and mathematics teacher. He argued that the reason for this result might be related to the discussion of environmental issues effectively in some courses (e.g. Social Project Development, Citizenship Knowledge, and Today's World Issues) which are only included in the undergraduate programs of social studies teacher candidates. Similarly, a study by Günal et al. (2018) compared biology and engineering students. The researchers found significant differences regarding ecological footprint awareness based on the program of study. They have concluded that the courses that biology students have taken on the subjects of ecology, ecological problems, ecosystems, and anthropogenic effects were the reason for their higher level of awareness.

In order to understand whether the programs of the pre-service teachers who participated to this study include topics related to environmental issues, the curricula for the three programs were examined. Examination of the three programs in terms of courses on environmental education revealed that student teachers in primary education department have taken an environmental education course. However other student teachers in science education and pre-school education departments have not taken any courses specifically focusing on environmental education in first two years of study. Based on this information, it might have been concluded that pre-service teachers' ecological footprint awareness might have reached its highest level before they started college and the 
courses they have taken do not have a considerable effect on the environmental awareness level.

\section{Conclusion}

The present research determined that pre-service teachers' awareness level of ecological footprint is considerably developed in energy dimension, relatively developed in water consumption and waste management. However, they have relatively low level of awareness on the food and shelter \& mobility dimensions. This result indicates a need of improvement specifically in food dimension of the ecological footprint awareness. A stronger emphasis on the environment-friendly food production and consumption is required in curricula of the related courses. For future research, conducting studies for developing an educational program specifically focusing on the food dimension and investigating the effects of it on development of ecological footprint awareness are recommended.

Education should be considered as the most important tool for raising awareness in people from an early age to reduce their ecological footprint. In addition, using various mass media (books, magazines, television, internet, etc.) might be a very effective way to this end. More importantly, it is specifically important for younger children to know that every living thing is a part of nature and to respect the nature by means of the experiences through their schooling and daily life. In order to achieve this goal, individuals should spend more time with in the nature. Having experiences with in the nature might have helped to gain a deeper understanding of the nature and to develop better attitudes toward it, consequently increase the ecological footprint awareness.

\section{References}

Ağaç, H., \& Yalçın, S. (2018). Üniversite öğrencilerinin ekolojik ayak izlerine göre kaç gezegene ihtiyacı var? Journal of International Scientific Researches, 3(2), 960-967. https://doi.org/10.21733/ibad.492268

Akıllı, H., Kemal, F., \& Okudan, K. (2008). Ekolojik ayak izinin kavramsal içeriği ve Akdeniz Üniversitesi İktisadi ve İdari Bilimler Fakültesinde bireysel ayak izi hesaplaması. Akdeniz İktisadi İdari Bilimler Fakültesi Dergisi, 15, 1-25. https://dergipark.org.tr/en/download/article-file/372643

Baykal, H., \& Baykal, T. (2008). Küreselleşen dünyada çevre sorunları [Environmental problems in a globalized world]. Mustafa Kemal Üniversitesi Sosyal Bilimler Enstitüsü Dergisi, 5(9).

Berenguer, J., Corraliza, J. A., \& Martin, R. (2005). Rural-urban differences in environmental concern, attitudes, and actions. European Journal of Psychological Assessment, 21(2), 128-138. https://doi.org/10.1027/1015-5759.21.2.128

Birand, A. (2016). Okul öncesi öğretmen adaylarının ekolojik ayak izi farkındalıkları ve çevre dostu davranışları. Yüksek Lisans Tezi.

Coşkun, I., \& Sarıkaya, R. (2014). Investigation of ecological footprint levels of classroom teacher candidates. Turkish Studies, 9, 1761-1787. https://doi.org/10.7827/TurkishStudies.6598

Eren, Ö., Parlakay, O., Hilal, M., \& Bozhüyük, B. (2017). Ziraat Fakültesi akademisyenlerinin ekolojik ayak izinin belirlenmesi: Mustafa Kemal Üniversitesi örneği. Gaziosmanpaşa Üniversitesi Ziraat Fakültesi Dergisi, 34(2), 138-145. https://doi.org/10.13002/jafag4315

Günal, N., Yücel-Işıldar, G., \& Atik, A. D. (2018). Üniversite öğrencilerinin ekolojik ayak izi azaltılması konusundaki eğilimlerinin incelenmesi. TÜBAV Bilim, 11(4), 34-46. Retrieved from https://dergipark.org.tr/en/download/article-file/616986

Hinds, J., \& Sparks, P. (2008). Engaging with the natural environment: The role of affective connection and identity. Journal of Environmental Psychology, 28, 109-120. https://doi.org/10.1016/j.jenvp.2007.11.001

Huddart-Kennedy, E., Beckley, T. M., McFarlene, B. L., \& Nadeau, S. (2009). Rural-Urban differences in

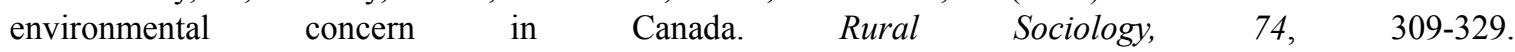
https://doi.org/10.1526/003601109789037268

Kahyaoğlu, M., \& Özgen N. (2012). Öğretmen adaylarının çevre sorunlarına yönelik tutumlarının çeşitli değişkenler açısından incelenmesi. Kuramsal Eğitimbilim Dergisi, 5(2), 171-185.

Karatekin, K. (2019). Model review Related to the effects of teachers' levels of ecological citizenship. International Electronic Journal of Environmental Education, 9(1), 46-61. Retrieved from https://dergipark.org.tr/tr/download/article-file/600693

Keleş, Ö. (2007). Application and evaluation of ecological footprint as an environmental education tool towards sustainable life (Ph.D Thesis, Gazi University, Department of Primary Education, Science Education Discipline, Ankara). 
Keleş, Ö. (2011). Öğrenme halkası modelinin öğrencilerin ekolojik ayak izlerinin azaltmasına etkisi. Gaziantep Üniversitesi Sosyal Bilimler Dergisi, 10, 1143-1160.

Keleş, Ö., Uzun, N., \& Özsoy, S. (2008). Measuring and evaluating pre-service teachers' ecological footprints. Ege Journal of Education, 9, 1-14.

Medina, M. A. P., \& Toledo-Bruno, A. G. (2016). Ecological footprint of university students: Does gender matter? Global Journal of Environmental Science \& Management, 2(4), 339-344.

Özbaş, E. E., Hunce, S. Y., Özcan, H. K., \& Öngen, A. (2019). Ecological Footprint Calculation. In N. Balkaya, \& S. Guneysu (Eds.), Recycling and Reuse Approaches for Better Sustainability. Environmental Science and Engineering. Springer, Cham. https://doi.org/10.1007/978-3-319-95888-0_15

Özgen, U., \& Demirci-Aksoy, A. (2017). Ecological footprint awareness levels of consumers (ample of Ankara province). Third Sector Social Economic Review, 52(3), 46-65.

Petrovic, N., Isljamovic, S., Jeremic, V., Vuk, D., \& Senegacnik, M. (2011). Ecological footprint as indicator of students environmental awareness level at Faculties of Organizational Sciences, University of Belgrade and University of Maribor. Management: Journal of Sustainable Business and Management Solutions in Emerging Economies, 58, 15-21.

Räty, R., \& Carlsson-Kanyama, A. (2009). Comparing energy use by gender, age and income in some European countries. Research Support and Administration, Swedish Defense Research Agency (FOI)

Sadık, F., \& Çakan, H. (2010). Biyoloji bölümü öğrencilerinin çevre bilgisi ve çevre sorunlarına yönelik tutum düzeyleri. Çukurova Üniversitesi Sosyal Bilimler Enstitüsü Dergisi, 19(1), 351-365.

Şahin, H., Erkal, S., \& Ateşoğlu, L. (2018). Determination of ecological footprint awareness of preschool teacher candidates. International Journal of Eurasia Social Sciences, 9(31), 1-12.

Tayc1, F., \& Uysal, F. (2012). Determination of the level of environmental knowledge, consciousness and environmental attitudes of elementary education students in Corlu, Turkey. Journal of Environmental Protection and Ecology, 13(2A), 1131-1138.

Wackernagel, M., \& Rees, W. E. (1998). Our Ecological Footprint. Reducing Human Impact on the Earth. New Society Publishers: Canada.

WWF (World Wildlife Fund for Nature). (2018). Living Planet Report. Retrieved from https://c402277.ssl.cf1. rackcdn.com/publications/1187/files/original/LPR2018_Full_Report_Spreads.pdf?1540487589

Yıldız, E. (2014). Fen ve teknoloji öğretmen adaylarının ekolojik ayak izi farkindalık düzeylerinin belirlenmesi ve değerlendirilmesi. Yayınlanmamış Yüksek Lisans Tezi, Gazi Üniversitesi Eğitim Bilimleri Enstitüsü, Ankara.

Yürüdür, E., Hastürk, G., \& Köklünar, S. (2017). İlköğretim 8. Sınıf öğrencilerinin çevreye yönelik tutumlarının belirlenmesi. Tarih Okulu Dergisi, 29, 447-466. https://doi.org/10.14225/Joh1041

Zengin, U., \& Kunt, H. (2013). Ortaokul öğrencilerinin ağaç ve çevreye yönelik tutumlarının incelenmesi. Mustafa Kemal Üniversitesi Sosyal Bilimler Enstitüsü Dergisi, 23(10), 155-165.

\section{Copyrights}

Copyright for this article is retained by the author(s), with first publication rights granted to the journal.

This is an open-access article distributed under the terms and conditions of the Creative Commons Attribution license (http://creativecommons.org/licenses/by/4.0/). 